\title{
Praestigiae Platonis: THE CAVERNOUS PuPPETSHOW
}

\author{
ALEXEI GARADJA \\ The Russian State University for the Humanities (Moscow) \\ agaradja@yandex.ru
}

\begin{abstract}
The paper deals with Plato's Allegory of the Cave at the beginning of the 7 th book of the Republic, focusing on the two lowest stages of the Cave (and the corresponding parts of the Line from the simile in the Sixth book), occupied, respectively, by 'prisoners and puppeteers'; the identity of these groups is questioned, along the lines set by J. Wilberding in his homonymously entitled article. The puppeteers and their show are examined with regard to the lexical peculiarities of Plato's text, in particular his usage of thauma and the derived thaumatopoios. The overall ironical, playful character of the Allegory is emphasized, calling for cautious reading beyond its apparent face value. A Russian term vertep, meaning both 'a cave' and 'a portable puppetshow', may prove itself helpful in approaching the sense Plato actually intended with his Allegory.
\end{abstract}

KEYWORDS: Plato, the Republic, Allegory of the Cave, vertep.

Plato's Allegory of the Cave breaching the Seventh book of the Republic has been discussed and commented upon since antiquity, mostly in conjunction with the Line simile which closes the previous book.

The question around which the majority of discussions of the Cave revolves is that of its parallelism to the Line. This question can be understood as having two parts: do both the Cave and the Line have four parts or stages, and if so, is there one-to-one correspondence between the parts of the Line and the stages of the Cave? At present, the orthodox interpretation answers each of these questions affirmatively. ${ }^{1}$

To me, of immediate interest are the two lower stages, played upon, resp., by 'prisoners and puppeteers,' as the title of the above quoted paper by J. Wilberding runs. The author would challenge the easy-going answer to the implied question about the identity of the two groups, viz. the multitude of the polis, 'ordinary

${ }^{1}$ Wilberding 2004, 117, cf. the note ad loc. with an expansive list of supporters and dissenters of this view in recent scholarship.

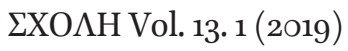

www.nsu.ru/classics/schole

(c) A. Garadja, 2019

DOI: $10.25205 / 1995-4328-2019-13-1-78-82$ 
men' prone to unreflective beliefs as the prisoners vs. 'legislators and politicians; poets, painters, and musicians; sophists and orators' as the puppeteers. ${ }^{2}$ Claiming from the Line simile the states of $\varepsilon i x \alpha \sigma i \alpha$ and $\pi i \sigma \tau i \varsigma$ for the two lowest stages and reassessing the account of $\varepsilon i x \alpha \sigma i \alpha$ to adequately suit both metaphors - with due regard for the often overlooked 'guessing game' in which the prisoners are engaged (R. $516 c 8-d_{4}$, e 7-8) -, Wilberding cogently sets the Allegory of the Cave in the proper perspective: the puppetshow corresponds to the multitude of citizens, craftsmen most of them, harboring 'unreflective' inherited opinions, while the lowest stage belongs to 'educated' personages - politicians, sophists, and the like - who but form opinions about opinions ('shadows on the wall'), with never a care about 'real things' (still a far cry from the Form of the Good), or rather without believing in their existence. It is them who are the prisoners in sooth, the self-inflicted victims of manipulation instead of manipulators.

Plato's writings - the Republic probably above all others - are saturated with subtle irony, sly suggestions and baits for the unwary reader favouring handsdown directness or blunt preconceptions of all kinds. Thus, by readily identifying puppeteers from the Cave with today's politicians or showmen, such readers fall easy prey to their own misapprehension - which was effectively set in place by the elaborate texture of Plato's text. So it is Plato who is pulling the strings, toying with his readers, like the gods in Lg. 644d7-e4:

let's imagine that each of us living beings is a puppet of the gods $(\theta \alpha \hat{v} \mu \alpha . . . \theta \varepsilon \hat{\imath} 0 v)$. Whether we have been constructed to serve as their plaything, or for some serious reason, is something beyond our ken, but what we certainly do know is this: we have

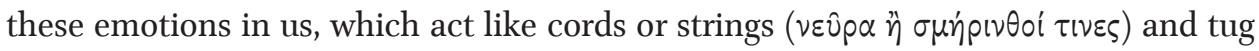
us about; they work in opposition, and tug against each other to make us perform actions that are opposed correspondingly; back and forth we go across the boundary line where vice and virtue meet. ${ }^{3}$

We encounter here a couple of rather embrangling expressions with uncertain or equivocal meanings provoking misinterpretations or calling for scholia. Such deliberate awkwardness - whether lexical or syntactical - is an artistic device of Plato's, as often as not used as a nota bene mark, a warning of a snare lurking in the text. ${ }^{4}$ It's up to the reader to blithely walk into the trap by taking the text at its face value, or be up to it and appreciate the text's intricate imbroglio. Skipping $\sigma \mu$ ńp

\footnotetext{
${ }^{2}$ Wilberding 2004, 119-120, with scholars' names and references in notes.

${ }^{3}$ Translation by Trevor J. Saunders.

${ }^{4}$ Cf. my remarks on Plato's word usage in R. 540e (Garadja 2017).
} 
interest to Hesychius and other lexicographers), we come up to $\theta \alpha \hat{\mu} \mu \alpha$ (resumed in the same sense of 'puppet' in the Allegory of the Cave).

$\Theta \alpha \hat{\jmath} \mu \alpha$ is used profusely by Plato in a number of dialogues in all its varying meanings: 1. wonder, marvel; 2. wonder, astonishment; 3. puppet (sg.), puppetshow,

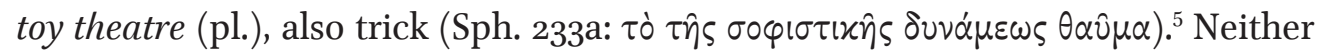
is uncommon in other ancient writers, including the sense of 'puppetshow' for $\theta \alpha v j \mu \alpha \tau \alpha$, with miscellaneous derivatives - 'mountebank-gambols', 'jugglerbooths', 'menageries', even 'mechanical devices' (LSJ). Still, Timaeus the Sophist feels the need for a clarification: $\theta \alpha v^{\prime} \mu \alpha \tau \alpha \cdot \nu \varepsilon v p o ́ \sigma \pi \alpha \sigma \tau \alpha{ }^{6}$

Let us recall the ways and trappings of Plato's cavernous puppetshow (R. 514b2-515a3):

Light is provided by a fire burning far above and behind them [= the prisoners fixed in their places by bonds that prevent them from turning their heads around]. Also behind them, but on higher ground, there is a path stretching between them and the fire. Imagine that along this path a low wall has been built, like the screen in front of puppeteers above which they show their puppets $(\theta \alpha \dot{\mu} \mu \alpha \tau \alpha) .\langle\ldots\rangle$ Then also imagine that there are people along the wall, carrying all kinds of artifacts $(\sigma x \varepsilon \dot{\eta} \eta \tau \varepsilon$ $\pi \alpha \nu \tau 0 \delta \alpha \pi \dot{\alpha})$ that project above it - statues of people and other animals, made out of stone, wood, and every material. And, as you'd expect, some of the carriers are talking, and some are silent. ${ }^{7}$

It is but shadows of these $\theta \alpha v \mu \alpha \tau \alpha$ that the prisoners can see cast by the fire behind them on the wall in front of themselves (515a7-8). There's quite a number of enlightening details to be found in this description. Wilberding, for instance, detects here confirmation for his 'unorthodox' interpretation of puppeteers, viz. that 'they stand for the group to which the politicians, sophists, and poets cater namely, the multitude consisting in large part of the polis's many craftsmen'. ${ }^{8}$ But

${ }^{5}$ Translations according to LSJ. Cf. respective renderings in Latin: 1. miraculum; 2. admiratio; 3. praestigiae (TGL), and French: 1. prodige; 2. étonnement; 3. marionette (Des Places 1964).

${ }^{6}$ Bonelli 2007: 151. Cf. Ruhnken's crisp definition of Plato's $\theta \alpha u ́ \mu \alpha \tau \alpha$ : praestigiae circulatorum, imagunculas nervis moventium, ut imperitum populorum stupore defigerent. Further on this scholar makes a point to distinguish between $\theta \alpha \cup \mu \alpha \tau \circ \pi \circ{ }^{\circ}$ ' 'who would stun ignorant people to stupor with their small string-driven images' and those 'who construct

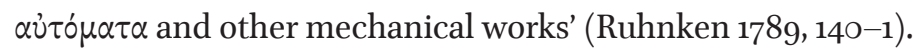

${ }^{7}$ Translation by G.M.A. Grube, revised by C.D.C. Reeve.

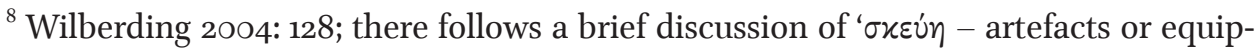
ment', but cf. my analysis of $\sigma \varkappa \varepsilon v \hat{\varsigma}$ (sg. for $\sigma \varkappa \varepsilon u ́ \eta)$ and derived $\sigma \varkappa \varepsilon \cup \eta$ 'theatrical paraphernalia, costume, etc.' in Garadja 2017: 77-80; Plato's Urtext may have sported at R.

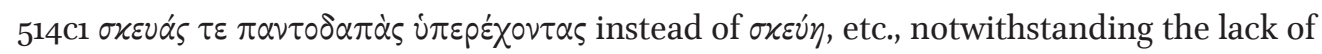
evidence for such a conjecture in the manuscripts. 
what strikes me most is that there is no mention of strings here in connection with

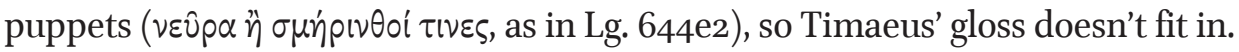

Plato's $\theta \alpha u j \mu \alpha \tau \alpha$ the shadows of which (515c2: $\tau \dot{\alpha} \varsigma \tau \hat{\omega} v \sigma x \varepsilon v \alpha \sigma \tau \hat{\omega} \nu \sigma x i \alpha \varsigma)$ the prisoners observe appear to be neither string-driven marionettes, nor glovepuppets like Punch and Judy. They are carried behind the screen by operators who alternately talk and keep silence - 'as you'd expect' (oív gixós). This is where the Russian вepmen comes in handy by way of analogy. It refers to a portable puppetshow performed on Christmas in remembrance of Nativity. There are generally two stages inside a two-tiered box (the upper for Heaven, the lower for Hell), inside which the puppets - dolls sitting on lengthy pins - are moved by manipulators holding those pins along slits cut in the bottom of each stage, to and fro. The personages, facing the audience, interact with each other only via the public: the performer would proclaim a puppet's monologue (or just plain self-presentation) and fall silent, expecting a response from the spectators - oiov Eixós (a trait of Medieval mysterial plays to which вepmen goes back to).

By a stroke of luck, the primary sense of вepmen is 'a cave, den'. Then a Russian-speaking reader may well descry in Plato's Allegory a вepmen en abyme, an abysmal theater inside another. It all may have been about pretence and illusion (as opposed to imaginative phantasy), which are the driving forces of a writer - and Plato was certainly one of the greatest, no less than he was a philosopher, and aware of the skein he was spinning. What I am hinting at here is not a real analogy, but an interpretative one. ${ }^{9}$ It is about how we should approach the work of such an ambidextrous writer-philosopher.

There's a lengthy train of interpretations of Plato's Allegory of the Cave, stretching from Neo-Platonists to present-day scholars. Still, there's a common strain in all of them - from religious ones (a mystical ascent to heavenly Light out of the squalid condition humaine) to epistemic or pedagogical (a no less mystical ascent to ultimate knowledge and dissemination of enlightenment amongst the lowly and ignorant) to political and sociological (focusing on democracy and its power games, including the obvious parallel between the puppetshow for the prisoners and today's media)..$^{10}$ The common preconception is that there necessarily should be something more or less real behind the Allegory, at the

\footnotetext{
${ }^{9} \mathrm{I}$ 'm not looking for real prototypes neither for Plato's puppetshow, nor for its settings - unlike, e.g., Gocer (1999) who would link the former to the modern Turkish Karagöz shadow puppet theater, then to its presumed Byzantine and Ancient Greek prefigurations, and finally to Aristophanic comedy; or Ferguson (1963) and others who would point to the real Cave of Vari on Hymettus as the settings for the show.

${ }^{10} \mathrm{Cf}$. Nehamas 1988, and interpreters of Straussian persuasion.
} 
bottom of the Cave, something that we should recognize and learn for our own good and general $\pi \alpha \iota \delta \varepsilon i \alpha$.

However, for a true philosopher, engaged in thinking as we are in living, there is nothing warranted, no achievement or failure is taken for granted, or as pending. He feels obliged to test multiple paths, and he tries them in company with his alter ego - a writer similarly engaged in writing —, probing, examining, weaving 'back and forth across the boundary line' between illusion and imagination, ignorance and knowledge, silence and utterance, strut and mask, lapse and exploit. There may be no hidden lesson to be retrieved from the Allegory, except only for this marvelous performative play in which the philosopher-writer Plato had ever been engaged.

\section{REFERENCES}

TGL = Thesaurus graecae linguae ab Henrico Stephano constructus. Ediderunt Carolus Benedictus Hase, Guilielmus Dindorfius et Ludovicus Dindorfius. 8 vols. Parisiis: excud. A. Firmin Didot, 1831-1865.

Bonelli, Maddalena, ed. (2007) Timée le Sophiste. Lexique platonicien. Leiden; Boston: Brill.

Des Places, Édouard (1964) Lexique de la langue philosophique et religieuse de Platon. P. 12. Paris: Les Belles Lettres.

Ferguson, John (1921) "Plato's Simile of Light. Part 1: The Similes of the Sun and the Line," The Classical Quarterly 15.3/4, 131-152.

Ferguson, John (1922) "Plato's Simile of Light. Part 2: The Allegory of the Cave (Continued)," The Classical Quarterly 16.1, 15-28.

Ferguson, John (1963) "Sun, Line, and Cave Again," The Classical Quarterly 13.2, 188-193.

Garadja, A.V. (2017) "Filosofy sebe zamutyat gosudarstvo (R. 540e)? [Philosophers to Rig Their Own Polis (R. 540e)?]," Platonovskiye issledovaniya 7.2, 71-83 (in Russian).

Gocer, Asli (1999) "The Puppet Theater in Plato's Parable of the Cave," The Classical Journal 95.2, 119-129.

Guthrie, W.K.C. (1975) History of Greek Philosophy. Vol. 4: Plato, the Man and his Dialogues: Earlier Period. Cambridge University Press.

Nehamas, Alexander (1988) "Plato and the Mass Media," The Monist 71, 214- 234.

Ruhnken, David, ed. (1789) Timaei Sophistae Lexicon vocum Platonicarum ex Codice MS. Sangermanensi nunc primum edidit, atque animadversionibus illustravit David Ruhnkenius. Editio secunda, multis partibus locupletior. Lugduni Batavorum: Apud Samuelem et Joann. Luchtmans.

Wilberding, James (2004) "Prisoners and Puppeteers in the Cave," Oxford Studies in Ancient Philosophy 27, 117-139. 